\title{
DESIGNING THE PESANTREN CURRICULUM TO COUNTER RADICALISM: Study on Pondok Pesantren Wali Songo Ngabar Ponorogo
}

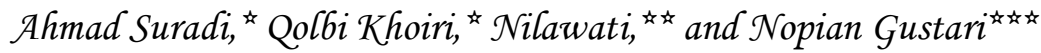 \\ * Institut Agama Islam Negeri Bengkulu, Indonesia \\ ** Madrasah Ibtidaiyah Nurul Huda Bengkulu City, Indonesia \\ *** Ministry of Religious Affairs Bengkulu Province, Indonesia \\ E-mail: suradi@iainbengkulu.ac.id
}

\section{Abstract}

This study aims to describe the moderate educational views of the Pondok Pesantren Wali Songo community in Ngabar Ponorogo and their efforts to prevent radical ideology. This is a qualitative research and the subject is the main source of data. The informants are the Kyai (the leader) and the Asâtîdh (the teachers) Council in the Pesantren. The results reveals that the Pesantren Wali Songo designed a curriculum that provided a comprehensive understanding of Islamic teachings. For example, the material of figh is embedded with uṣ̂ul al-figh. In usûl al-fiqh, there are rules of istinbât al-hukm besides the Quran and hadith such as ijmâ', qiyâs, 'urf, mașlahah almursalah, and maqâsid al-sharî́ah so that fiqh is flexible. In addition, the Pesantren recruited a board of teachers who had moderate understanding and background in kaffah Islamic ideology. Santri (the students) are protected from information access and certain association which lead to radicalism. In developing moderate Islam, the curriculum there require them to study books that explain the understanding of Islam Ahl al-Sunnah wa al-Jamâ'ah.

Kajian ini bertujuan untuk mendeskripsikan tentang pendidikan moderat masyarakat Pondok Pesantren Wali Songo Ngabar Ponorogo dan upaya mereka dalam mencegah masuknya paham radikal. Metode penelitian yang 
digunakan adalah penelitian kualitatif. Subjek penelitian adalah sumber utama dalam penelitian, juga dapat dikatakan sebagai sumber data. Mereka adalah Pengasuh/kyai dan Dewan guru/asatidz yang ada di pesantren ini. Hasil penelitian ini mengungkapkan bahwa Pesantren Wali Songo merancang kurikulum yang memberikan pemahaman yang komprehensif tentang ajaran Islam. Misalkan materi figh dimbangi dengan meteri ushul figh. Dalam mata pelajaran ushul figh terdapat kaidah-kaidah istinbât alhukm (cara pengambilan hukum) selain dari Al-Qur'an dan hadis seperti ijmâ', qiyâs, 'urf, mașlahah al-mursalah, dan maqâsid al-sharî'ah sehingga hukum Islam (figh) bisa dipahami secara fleksibel. Selain itu, Pesantren Wali Songo melakukan rekrutmen dewan guru yang memiliki pemahaman moderat dan memiliki latar belakang idiologi Islam kâffah. Para santri juga diproteksi dari pergaulan dan akses informasi yang mendorong tumbuhnya radikalisme. Pesantren Wali Songo dalam mengembangkan Islam yang moderat adalah melalui kurikulum dilakukan dengan pembelajaran kitab yang membentuk pemahaman Ahl al-Sunnah wa al-Jamâ'ah.

Keywords: curriculum; counter radicalism; pesantren

Received: January 13, 2021; Accepted: April 27, 2021

\section{Introduction}

The crisis of ideology faced by Muslim society in Indonesia has an impact on the genesis of religious movements that legitimate violence and terrorism (Ma'arif, Sebastian, and Sholihan 2020). They are usually intolerant of followers of other religions, or of different ideas. Radical Islamic style shows fanaticism and exclusivity, they often force their understanding and consider it to be the most correct. So, the emergence of Islamic radicalism is mainly triggered by the combination of the ruling regime's political repression, crucial socio-economic deprivation, globalisation, and Arabia support (Muzakki 2014, 1). This exclusive attitude breeds radicalism in religion and will be dangerous if it reaches the level of ghuluw (transgressing) and ifrât (outrageous) when forced upon followers of other religions (Laisa 2014, 2). Those harmful acts include the sweeping action of non-Muslim attributes during the Christmas commemoration, anti-immoral acts i.e. consuming narcotics, Islamic constitutionalism, and claiming others heresy since their understanding is not in line. The more extreme act is bombings in some churches and public facilities in the name 
of jihâd such as the Bali bombing case on October 12, 2002 which killed 200 people committed by Imam Samudra and his colleagues (Tan 2011, 22).

Such attitude certainly cannot be separated from the teaching doctrine. This is also in line with the educational system or from the results of learning the doctrine. From here, it seems that education is the most important entity in shaping one's religious character and attitude.

Peace culture is an atmosphere in which there are values of tolerance and acceptance towards other communities. In Islam, tolerance is a product of understanding Islamic theology. Therefore, looking at the potential for peace in Islam community must be seen through their interpretation of Islamic theology related to hot issues triggering violence (Sholeh 2007). After understanding their perspective, the next step is to see the implementation in the form of action such as socialization or education to the society.

One of the educational institutions that specifically teaches the basics of Islam (theology) is Pondok Pesantren (or Pesantren-Islamic boarding school). It is a traditional Islamic educational institution in Indonesia. Pesantren in general, teaches a culture of peace and shows a more moderate Islamic character because in general it is part of the Sunn $\hat{\imath}$ community that is widely embraced by the Indonesian Muslim (Marzuki, Miftahuddin, and Murdiono 2020).

The moderate character and peaceful culture of pesantren cannot be separated from its educational model. Many pesantren aim to be flexible, open, but cautious to the outside world (Susanty 2016). The dialogue process illustrated in thebooks learned there shows its dynamics of thought. Through classical books (people in pesantren usually call it Kitab Kuning, yellow books), students in pesantren discover and study the scholars' diversity of opinions (Baso 2007, 112). The educational system in pesantren exposes the students to the "khilâfiyah" point of view contained in the classical books. That way, they will learn to be open-minded and accept different opinions. They also can shape their critical thinking skills on new issues.

Besides the educational model explained above, the world of pesantren is very respectful toward the community's traditions. History wise, pesantren is part of an accommodative form of culture and values of Islamic teachings. It is a combination of the Zawiyah tradition (traditional school for spiritual training) developed in the Padepokan tradition (Hindu-Buddhist college) in the archipelago for centuries. The meeting between the two different 
cultures is a combination of Zawiyah substance which contains Islamic teachings and the structure and method of Padepokan that has taken root in Archipelago society (Mun'im 2016, 39).

The above description strengthens the initial observations that Pondok Pesantren Wali Songo, Ngabar Ponorogo (henceforth Pesantren Wali Songo) has a distinct character as a cultural heritage. They develop their own tradition in terms of scientific thought, language, and dress code. They are even able to maintain a plurality of understanding on the Islamic Archipelago and Islamic relations with various communities under the principle of tolerance (Observation, Ponorogo, December 11, 2019). Such traditional foundation makes the pesantren community accommodate the local traditions without ignoring the substance of Islamic teachings values. In practice, Pesantren Wali Songo, as a Muslim group with madhhab (school) of thought, is not only satisfied with the doctrine, but tries to seek its relevance for real life in society. This effort then encouraged Muslims to meet and mingle with local culture.

Seeing the characteristics, this pesantren definitely is in contrast to the ideas and thoughts of radical groups that deny local culture because they are considered syncretic (Kadi 2008). It is proven that this pesantren rejects Islamic radicalism which is considered to have developed in pesantren community. Besides, the social role of Pesantren Wali Songo, both kyai and santri, is very strategic to be portrayed in the context of diversity interaction, especially related to ukhuwah wataniyah (nationhood) and ukhuwah bashariyah (brotherhood of humanity) (Nurcholis 2019). Through its alumni, they develop and traditionalise a peaceful culture of pesantren in the community (Kurniadi 2019).

The previous research results, as observed by Setiawan, that pesantren combines the classical and modern curriculum. It is proven to be applied well in the teaching and learning system (Setiawan 2013). Meanwhile, this research discusses pesantren's peaceful culture by developing the attitude of ukhuwah wataniyah and ukhuwah bashariyah in the context of Bhinneka Tunggal Ika (Unity in Diversity) and wisdom in responding to local culture in accordance with the teachings of Ahl al-Sunnah wa al-Jamâ'ah (Sunnî school of thought). This effort can neutralize and minimize the influence of radical understanding, and terrorist movement in the name of jihâd. The researchers focus the study on how the Pesantren Wali Songo designs the curriculum to counter radicalism. 


\section{Method}

This is a qualitative research i.e. the process to explore and understand the meaning of individual and group behavior, describe social or humanitarian problems. The data collection relies on participant settings, inductive data analysis, building partial data into themes, and then providing interpretations of the data. The approach in this research is phenomenology because the researchers identify particular phenomenon and study the subject by being directly involved.

The research subject is the main source of investigation or data source. It is chosen through purposive sampling technique. The subjects of the study are Kyai (the leader) and the Board of Asâtîdh (the teachers) in Pesantren Wali Songo. This research was conducted in December 2019 to January 2020. The analysis steps taken in this study are:

1. Data collection is done through observation, interviews, and documentation

2. The data is reducted by simplifying the obtained data

3. The data is then collected and presented to obtain clear information about Islamic anti-radicalism education models in pesantren (Islamic boarding schools).

4. After analysis and discussion, the researchers resume the information in order to get definitive conclusions.

\section{Moderate Islamic Education Development Strategy}

Moderate Islamic education is basically included in educational value, namely moderate Islam. Therefore, educational system must help students to experience these moderate values and integrated it in their whole lives. To make the educational value effective and successful, Notonagoro provides the steps in learning process (Adisusilo 2013, 72):

1. Educators must first know and understand deeply what values they will teach. They also should be clear with their minds.

2. Educators transform these values by touching students' heart and feelings so that students can see the goodness of the values.

3. Assist students (santri) to internalize the values so it becomes a part of life. It means that the values become their nature, attitude, and the basis for behavior.

4. Life attitudes that are in accordance with these values are encouraged to realize them in daily life. 
In teaching moderate Islamic values, the things that Pesantren Wali Songo did were through modeling of Kyai, curriculum and daily practices. Some strategies in moderate Islamic education are as follows:

1. Kyai as a role-model

Exemplary is an ideal exposure that should be followed in this pesantren. Kyai is a reflection of the behavior followed by students at Pesantren Wali Songo (Ihsan 2020). According to Mas'ud, in the world of pesantren, modeling, exemplary, uswah hasanah is interpreted as tashabbuh, the process of self-identification in a person, the 'alim (Mas'ud 2007).

The field research proves that kyai's role is very important and very influential. He is the sole leader who holds an almost absolute role. The charisma of a kyai at Pesantren Wali Songo makes him highly respected by their students. Hence, a kyai must be a role model for students in pesantren. His role is crucial in determining the success of pesantren's education system. His attitude becomes the foundation of students' character.

In Pesantren Wali Songo, the exposure of Kyai's moderate attitude is reflected in his teachings and daily behavior. It is shown especially in dealing with problems of daily life, political and cultural situations, and in treating students. One of examples from Kyai in showing the moderate values is by holding on to the principle of Bhinneka Tunggal Ika (Unity in Diversity). This attitude is shown in responding to differences within pesantren and respect others.

According to Kyai, if a culture does not cross religion line, it can be practiced/done. On the contrary, if it is not in line with religious teachings, it must be rejected-definitely in a polite and gentle manner. He also explained that if something can still be explained with the correct logic, then it can be continued and be guided without coercion and violence (Ihsan 2020). The persistence of the kyai in holding religious principles is always based on the logic of thinking that is suitable with the present values. Moreover, if we are living in a society with many differences, a wise attitude is always emphasized in dealing with all problems including in educating children. These attitudes and views are then modeled and imitated by the students.

Ziemek states that the leadership style shown by kyai proves his abilities and radiant personality as a leader of an Islamic boarding school. This, then, also determines the position and quality of a pesantren (Ziemek 1997, 138). What needs to be emphasized here is that the figure of kyai as 
the leader is a picture of santri (pesantren's students) in carrying out activities in the domitory especially in shaping their character.

2. Learning Process: Teaching the values of Ahl al-Sunnah wa al-Jamâ'ah

In understanding Ahl al-Sunnah wa al-Jamâ'ah inherited by al-salaf alsâlih in Pesantren Wali Songo, it was realized through curriculum of the salaf books. Ahl al-Sunnah wa al-Jamâ'ah covers three aspects in Islam i.e. faith, sharîa (figh) and morals or tasawwuf. These three aspects become the orientation of Kitab Kuning (traditional Jawi texts on Islam) taught in the mentioned pesantren. The books are written by previous scholars (salaf) used as a source of understanding Ahl al-Sunnah wa al-Jamâ'ah.

Here are some books learned in Pesantren Wali Songo; in the field of 'Aqî̀dah:'Aqîdat al-Awâm, Kifâyat al-Awâm, Jawhar al-Tawhîd, and Nûr alZalâm; in the field of Jurisprudence: Safinat al-Najâh, Fath al-Qarîb, Fath alMu'în, Sullam al-Tawfíq, Kâshifat al-Sajâa, and Fath al-Wahhâb; in the field of Sufism: Adâb al-Âlim wa al-Muta'allim, Ta'lîm al-Muta'allim, Taysir al-Khallâq, Akhlâq al-Banayn, Minhâj al-ÂAbidîn, Irshâd al-Ibâd, al-Adhkâr, 'Izat al-Nâshi'în, al-Tahliyat wa al-Targhîb al-Fitr Fatwâ li al-Nawawî, and 'Umdat al-Sâlik wa 'Idat al-Nâsik.

The contents of the books complete one another and at the same time shape students' personality. It also teaches the true Islamic monotheism, Islamic law (figh), and the morality of a typical Islamic boarding school. The books cover various fields of Islam and its disciplines. The broad scope forms an inclusive, substantive, and comprehensive understanding. Knowledge learned from these books is immediately practiced in pesantren environment and directly monitored by kyai or teachers.

It is optimal to teach about Islam through Kitab Kuning written by scholars of Salaf. Almost all aspects of Islam are written in the books, for instance: the Quran, 'aqîdah, fiqh, tafsîr (Quranic exegesis), hadith, târikh (history), language, Sufism to social ethics and culture (mu'âmalah). Simultaneously the contents of the books were applied in pesantren daily life shown through kyai/ustâdh's habits. It is expected that students have broad understanding, attitude and behavior with consideration of their in-depth religious knowledge. So, they have an open horizon, inclusive and wise attitude in responding to the problems they face, especially in the religious field. 
The plurality of thought the books studied at the mentioned pesantren is a separate phenomenon for the formation of students' views and personalities in facing reality within society. Furthermore, there is also dialogue among various disciplines, for example figh and usûl al-fiqh, monotheism and Sufism, târikh (history) and mu'âmalat, and Arabic and interpretation (hadith or the Quran). All disciplines complement each other. 3. National education insight

National education is one of pillars of moderate Islamic character. Nationalist insight is one's view on the nation and state. If we are to break down the meaning of nationality insight; insight is views, reviews, visions, sensory responses. In other terms, insight means understanding or belief about a matter, perspective, method of review and method of sensory response. Meanwhile, nationality comes from the word 'nation' defined as a group of people who are the descendants of the same ancestors (Azra 2016, 83). The term nationality is generally associated with characteristics of people which has elements in the form of brotherhood, ancestry, customs, history, and government system. Thus, nationality is the development result of a dynamic sense of nationalism in achieving the ideal nation. The national insight finally gave a concept of nationalism, namely national thoughts, where a nation has ideals of life and national goals.

Indonesia is a country that consists of various ethnicity, race, nation, culture, religion, and language. With that in mind, to prevent the emergence of radical ideas and strengthen the character of moderate Islam, it is necessary to instill a nationalist insight. The goal is for the students to have a knowledge horizon about the differences exist in Indonesia and to strengthen sense of nationalism. From here the students can play an active role in a pluralistic society and contribute to create conducive atmosphere and take part in achieving national goals.

4. Practice of Habituation

a. Habituation of Islamic traditions

Besides teaching Islamic values through curriculum in pesantren environment, it is also carried out through efforts to actualize Islamic values in daily life (Zainiyati 2016). Islamic values in daily life are embodied in the traditions that developed inside and outside pesantren. Among the traditions performed at Pesantren Wali Songo are reading of Tahlîl (praying for the deceased person) and Istighathah (asking for God's help). These traditions are a form of actualization of Islamic teachings that have existed since the 
period of Wali Songo (nine preacher in Java island) and still remain. The tradition that developed in society then gained legitimacy from the pesantren

In the study of usîl al-figh, the issue of tradition (al-furû) received considerable attention. Among the four popular schools of jurisprudence (Hanafî, Mâlikî, Shâfi î, and Hanbalî), two of them (Hanafî and Mâlikî) use tradition as the foundation of istinbat t and see it as a basic principle of foothold of the pilgrimage, as long as the tradition is in line with the certain texts (nasss qat'î). In Shâfi î school (al-fur $\hat{u})$ ), it is also noted that there are no texts or other bases in the form of ijmấ or qiyâs which can be used as a basis for conducting ijtihâd. The same thing applies to Hanbalî (Mas'ud 2010).

In the connection between culture or tradition and religion at least according to Bagir there is a positive view, namely as a source of wisdom and as a legacy of divine wisdom (Bagir 2015, 177). The tradition that developed in pesantren particularly and society in general is a source of local wisdom to realize harmonization of life in the community (Ma'arif 2019).

Pesantren Wali Songo which has long historical roots in society, especially the surrounding traditionalist communities, in teaching Islamic values cannot be separated from the struggle of tradition. This traditional approach is proven successful in instilling Islam peacefully in the surrounding community, which is coming to seep in peacefully and slowly but surely. Festival activities "solawat and qasidah" from "karawitan" to "tambourine", and almsgiving to "walimahan", constitute the conversion of pre-Islamic values into new Islamic values.

b. Habituation through commemoration of national holidays

Commemoration of national holidays is the most appropriate momentum to instill the spirit of nationalism to students. National holidays at Pesantren Wali Songo are usually commemorated by holding a flag raising ceremony. Some national commemorations celebrated there are the Proclamation of Independence of the Republic of Indonesia every August 17, Heroes' Day, and Santri Day. These are done to reminisce the struggles of the heroes (Nurcholis 2019).

Ceremony like these for radical groups is considered harâm. They say that it is respecting inanimate objects, thus, it is shirk. This assumption was deemed wrong by the Pesantren Wali Songo community, because respecting the flag is essentially respecting the heroes who have sacrificed everything and even their lives in order to gain independence. The Red and White Flag (Sang Merah Putih, Indonesian flag) shows that independence has been 
achieved. Here is the significance of honoring the flag with a sense of obligation in maintaining independence and filling it with positive actions for nation building.

c. Regional organization activities

The regional organizations (known as orda-organisasi daerah) in Pesantren Wali Songo are students based on their respective regions. The aim is to introduce the potential of the respective regions of the santri. Besides, Orda functions as a place to learn together and to facilitate learning of certain materials according to the schedule determined by the pesantren, for example khitâbah exercises (speeches), recitation of zhiba', Mawlid of the Prophet Muhammad PBUH which is scheduled on every Friday night and Tuesday night (Marjuni 2020). These activities are carried out so the students are no longer awkward when directly involved in the community. For new students, this is very useful because they can practice their confidence. As a result, they have to be coercive so they want to make a speech in front of friends.

\section{The Conception of Pesantren Society on Understanding Religious Radicalism}

The radical understanding of religion according to pesantren's Kyai is primarily a model that is not in line with moderate Islamic understanding which is more likely tolerant toward differences (Ihsan 2020). As stated by Ustâdh Toha in an interview, radicalism is a textual understanding, exclusive and often uses instruments of violence in delivering the teachings. This is different from what was developed at the Pesantren Wali Songo where Islam is taught in a friendly manner (Toha 2019).

Abdullah states that radical actions in Islam are mostly caused by Muslim interpretations of the Quran and the Sunnah which are textual, scriptural and rigid. They are not interpreted contextually which involve the historicity of the text and its dimensions. The verses that tend to lead to acts of violence, such as verses about kufr, shirk and jihâd. They are often interpreted as they are, regardless of their sociological and historical context. In its extreme example, such tendencies have prevented some Muslims from being able to clearly understand the messages of the Quran as a divine instrument that provides a true guide to moral and ethical values for human life (Abdullah 2016, 21). 
Based on some of explanations above, radical ideology in Islam often arises from a narrow view and understanding on Islamic teachings. For example the teachings about jihâd, relations with non-Muslims, the enactment of Islamic law, acceptance of the Pancasila and the 1945 Constitution (Undang-Undang Dasar 1945) as the basis of the State, as well as greetings to different religions.

The doctrine of reviewing the Quran and the Sunnah is more intended as a command to return to the roots of early Islam and the authentic practices of the Prophet. This is then understood by the radicals as returning to Islam in a kâffah way, namely an obsession back to the past as a whole without seeing the socio-cultural changes that have been experienced by Muslim societies today (Hakim 2016).

The construction of radical understanding which is based on textual interpretation is what later gets its enthusiasm in the doctrine of jihâd to fight for kâffah Islam. In the name of jihâd, according to radicalism, a person is justified in carrying out radical actions. Jihâd becomes an ideology and an instrument that moves to take radical action in order to change the secular order into an Islamic order (Saifullah 2014).

According to KH. Heru, jihâd in Islam is a command that has been stipulated in sharia (Heru 2019). In reality, it is understood in a varied way by the community, including religious educators (kyai and ustâdh/ustâdhah). This difference in understanding jihâd is actually influenced by the level of religious mastery, experience, knowledge, and social conditions.

In the view of the kyai of Pesantren Wali Songo, jihâd should not only be understood narrowly as war, but also interpreted in a broad sense encompasses all activities that demonstrate the struggle for God, especially in the field of education to educate Muslims. Meanwhile jihâd in the sense of war is understood only when Muslims are attacked by the enemy (Nurcholis 2019).

Meanwhile, the ustâdh/ustâdhah (teachers) of Pesantren Wali Songo state that social relations with non-Muslims, such as trading, dealing, associating, making friends, etc. in principle, is no problem. In terms of choosing Muslim leaders, it needs to be understood that Indonesia is using a democratic system that everyone has the right to become a leader both Muslim and non-Muslim. However, Muslims should choose leaders who are Muslim while having leadership characteristics that are in accordance with Islamic teachings namely mandate, honesty, fairness and always prioritize 
the people (Ihsan 2020). However, it is different from the view of the radicals, that the implementation of Islamic sharia is the state ideology, is deemed necessary as an effort to run Islamic kaffah (as a whole). The reason is because by implementing Islamic sharia as the basis of the state, all problems can be solved by returning to the Quran and Sunnah. According to them, the Quran and Sunnah has covered all aspects of life (Masduqi 2012, 82).

Another teacher said, although Indonesia is not an Islamic state, it is a safe and peaceful country where people live the Islamic teaching values. So, the state does not have to implement Islamic teaching as the basis. What is more important is that the people live the Islamic values and the law is not substantively against Islamic teachings. Considering that our country consists of various religions, ethnicities, and cultures, it is impossible to accept Islam as the sole principle because it will be rejected by non-Muslim groups. Muslims must realize, for the unity and integrity of Indonesia, they must not force Islamic law into the state's principles (Nahrowi 2020).

Regarding the implementation of khilafah system forced by radicals, the Kyai of Pesantren Wali Songo believes that Indonesia does not need such system, because in Islamic sources there is no government system that governs the country (Ihsan 2020). Although in Islamic history there is a khilâfah phenomenon, but there is no standard concept of khilâfah, for example the al-Khulafâ' al-Râshidûn government system. In their journey, the system was different in appointing a caliph, for example Caliph Abû Bakr was chosen through a consensus agreement, Caliph 'Umar was chosen through the mandate of Abû Bakr, the Caliph 'Uthmân was chosen through a team (ahl al-hall wa al-'aqd), Caliph 'Alî was chosen by acclamation or majority of the people. The khilafah system then continued on the period of the Umayyads, then to the Abbasids who tended to be monarchical (hereditary in the royal system). Thus, in principle, the caliph leadership system in Islamic teachings is not found.

Indonesia is a democratic state. Pancasila and the 1945 Constitution is the right basis to unite various religious, ethnic, culture and island in the frame of the Republic of Indonesia. Therefore, we can say that the emergence of radicalism in Indonesia is caused by a narrow, textual, scriptual, and rigid understanding without looking at the historical and socio-cultural aspects. Such understanding triggers violation and even terrorism. They tend to have a few insight on the verses containing the 
sword (jihâd), disbelief (takfir), and tashrîk. They prefer to choose pro-war verses than the ones which explain about peacefulness.

\section{Pesantren's Efforts to Counter Radicalism}

Pondok Pesantren as a religious education institution always plays a strategic role, especially in influencing the mindset, knowledge, understanding, and religious behavior of Indonesian Muslim communities (Fahham 2015). Through the education system, pesantren uses it as a tool for overall cultural and social transformation in people's lives, not only in the field of religion (tafaqquh fi al-dîn), but in all aspects of life (Bizawie 2014; Dhofier 2011).

Pesantren is considered populist and can be seen as a miniature of community. Students learn to socialize inside and outside pesantren environment (Nuryanti 2014, 82). As a miniature of community, it has dynamics in dealing with social change (Mas'ud 2010). Amid the social change and the tug of religious influence, pesantren has a role in shaping the religious character of the santri and society in general, especially amid the growth of radical movement.

Pesantren Wali Songo develops a moderate understanding of Islam by following the teachings of Ahl al-Sunnah wa al-Jamâ'ah which characterize tawâzun, tawassut, and tasâmuh. They are confronted with the problem of radicalism that develops in a society which is in sharp contrast to the character and traditions of pesantren (Saiful 2019).

It is important for them to build the mindset and behavior of religious students who carry out preventive efforts towards radical understandings. The efforts made by the pesantren in protecting students are as follows:

1. through the curriculum

The curriculum is the main capital in building the mindset and behavior of the community, especially students who will dive into the community. The curriculum at Pesantren Wali Songo is basically fundamental and has the potential to be interpreted radically, especially those that rely on the subjects of faith, figh, and interpretation (Nurcholis 2019). These three subjects provide knowledge to respond to the social conditions as well as the construction of religious understanding which has the tendency for radicalism, especially in discussing the issue of jihâd, infidelity and Islamic law. If it is understood dogmatically and radically, it 
will have the potential for radicalism. On the contrary, if understood contextually or moderately, it can minimize the radicalism mindset.

In counteracting a radical understanding, there needs to be a counterweight to comprehensively understand the teachings of Islam. In Pesantren Wali Songo, the subject has received a balance. For example, fiqh is balanced by usûl al-figh. In usûl al-figh, there are the rules of istinbât al-hukm (how to make law) apart from the Quran and the hadith such as ijmâ', qiyâs, 'urf, mașlahah al-mursalah, and maqâsid al-sharî'ah. So, there is a flexibility in understanding Islamic law (figh), because there are rules that align between text and reality.

In the teaching of faith, according to Al-Makassary to ward off radical understanding, it should be balanced with moral material (Al-Makassary 2011). By studying morals, students are taught how to behave and relate well with fellow human beings (habl min al-nâs). From here, then the attitudes and movements of a person will be tolerant with people of different religions.

In studying tafsîr, students require a set of knowledge in interpreting the Quran and the hadith. It includes the science of asbâb al-nuzûl, asbâb alwurûd, nâsikh-mansûkh, history, qirâ'at, mustalah al-hadîth, rijâl al-hadith besides mantiq and bayân, even usûl al-figh. With this set of knowledge, it is hoped that the Quran and hadith can be comprehensively understood and intact, so that it can be substantially implemented in daily life according to the time conditions (sâlih li kulli zamân) based on the text history.

2. Recruitment of Ustâdh (teachers)

The next effort in protecting students from radical understanding in Pesantren Wali Songo is in the selection of teachers, especially those teaching in formal schools. Meanwhile, the kyai teaching in the halls are recruited from senior students, graduates and kyai from other institutions. In terms of recruiting religious teachers, Pesantren Wali Songo bases on the competence and educational background especially the alliance or "ideology" (Ihsan 2020). Educators (teachers) are recruited from those who have the understanding of Ahl al-Sunnah wa al-Jamâ'ah and do not have radicalism understanding.

Religious understanding is often associated with the views and attitudes of a person or group that is influenced by religious teachings in seeing the problems (Masduqi 2012; Eliraz 2007). The religious and educational background of a teacher becomes important to consider in 
order to protect students from radicalism. According to Ihsan, If they found a radical kyai (those who have activities outside pesantren which are part of Partai Keadilan Sejahtera, Front Pembela Islam, Hizbut Tahrir Indonesia etc.) then the institution will have special treatment to face that, for the sake of students (Ihsan 2020).

3. Protection through association and access of information

Pesantren is a subculture, as termed Abdurrahman Wahid, which has its own traditions and relationships (Wahid 1999, 13). The patterns of association and traditions that exist in pesantren are separate from general community. The values developed in pesantren are designed by kyai or founders. So, the character of pesantren is sourced from kyai's understanding. These values are then developed in the process of association in pesantren (Suyudi and Rahmatullah 2017). The values are based on the understanding of Ahl al-Sunnah wa al-Jamâ'ah which has moderate character, so the contrary values cannot be accepted in this pesantren, especially radicalism.

As we know that pesantren is a place for students to study Islam. The pattern of association in pesantren cannot be separated from the existence of students. The patterns of students association in the Pesantren Wali Songo are inseparable from a number of factors surrounding them, including kyai, religious teachers, other students, and the environment. In the learning process, these factors will interact one another, so there are various interactions within pesantren, both between students and kyai, students and fellow students, and also students with the environment. Interactions in this pesantren are individual and group.

In the process of social relationship in Pesantren Wali Songo, students basically influenced by both internal and external factors. Internal factors include words, deeds, or behavior and personality. This internal factor cannot be separated from external factors. While external factors are the family environment, boarding schools and the wider community that has helped shape the personality of the students.

The next process, the behavior of Pesantren Wali Songo students are also influenced by the innate personality, namely the one carried by santri before he enter the pesantren. Also, it is affected by interaction developed and enforced by the pesantren managers, based on both written and unwritten rules (Pesantren Wali Songo association). In practice, this last social pattern requires time for the students to adapt. 
In the association, to prevent radical understanding, pesantren detects students' behavior through daily activities such as in learning activity with religious teachers and kyai. This detection is not difficult. Social interaction with the kyai and religious teachers in pesantren is a must. Santri as knowledge seeker, while the educators (kyai and religious teachers) as the knowledge carrier. Students must abide by the various norms, rules, and values in pesantren either the values contained in the book or in the form of advice of kyai. This way, it is expected to easily detect radicalism and how to prevent and foster it.

Pesantren Wali Songo as an Islamic institution based on Ahl al-Sunnah wa al-Jamâ'ah, who has a moderate character and mission to support the national development by providing flexible human resources, definitely rejects radical ideas, especially those that lead to rejection of the Pancasila and the 1945 Constitution Pesantren Wali Songo firmly prevents students who were detected having radical understandings so as to have moderate attitudes and views.

Furthermore, effort to prevent radicalism in the aforementioned pesantren is by monitoring the media developed in the school. It is by selecting the readings, references and information. The kyai were instructed to be careful in giving information media to the students and not to let the material contain radicalism, even in the radio. The radio owned by pesantren was established to provide good information and at the same time as a propaganda media that develops ideas including the teachings delivered by the kyai in conveying Islamic understandings which are rahmat li al'âlamîn. With these media, Pesantren Wali Songo counters radicalism by developing ubudiyah, mu'âmalah, humanism, ethics (morals) in society, harmony, tolerance, mutual respect among fellow members of society despite differences, nationalism and how to be good citizens.

\section{Conclusion}

Pesantren Wali Songo designed a curriculum providing a comprehensive understanding of Islamic teachings. For example, the material of figh is connected to ușul al-figh. In the subject, there are rules of istinbat al alukm (how to make the law) apart from the Quran and hadith such as ijmâ', qiyâs, 'urf, mașlahah al-mursalah, and maqâsid al-sharî'ah so that we understand that Islamic law (figh) is flexible, because there are rules that harmonize text and reality. In addition, the pesantren recruited a board of 
teachers who had a moderate understanding and background in Islamic ideology. In developing moderate Islam, they do it through a curriculum by studying books that teach the understanding of Islam Ahl al-Sunnah wa alJama'ah and habituation through activities that form the character of moderate Islam.

In developing moderate Islamic values, the most important thing is to teach Ahl al-Sunnah wa al-Jamâ'ah understanding through modeling by the kyai, curriculum, and habituation. Curriculum wise, it is done by learning books that form the understanding of Islam Ahl al-Sunnah wa al-Jamâ'ah and habituation through activities that form a moderate Islamic character.

\section{References}

Abdullah, Anzar. 2016. "Gerakan Radikalisme dalam Islam: Perspektif Historis.” Jurnal Addin: Media Dialektika Ilmu Islam 10(1): 1-28. DOI: http://dx.doi.org/10.21043/addin.v10i1.1127.

Adisusilo, Sutarjo. 2014. Pembelajaran Nilai-Nilai Karakter: Konstruktivisme dan VCT Sebagai Inovasi Pendekatan Pembelajaran Afektif. Jakarta: Rajawali Pers.

Al-Makassary, Ridwan. 2011. Benih-Benih Islam Radikal di Masjid: Studi Kasus Jakarta dan Solo, ed. Ridwan al-Makassary. Jakarta: CSRC UIN Syarif Hidayatullah.

Asror, Ahidul. 2012. "Rekonstruksi Keberagamaan Santri Jawa." Islamica: Jurnal Studi Keislaman 7(1): 1-23.

DOI: https://doi.org/10.15642/islamica.2012.7.1.1-23.

Azra, Azyumardi. 2016. Transformasi Politik Islam: Radikalisme, Khilafatisme dan Demokrasi, Jakarta: Prenadamedia Group.

Bagir, Haidar. 2015. "Islam dan Budaya Lokal." In Islam Nusantara dari Ushul Hingga Kebangsaan, eds. Akhmad Sahal and Munawir Aziz. Bandung: Mizan Pustaka.

Baso, Ahmad. 2007. "Islamic boarding school dan Kultur Damai: Pengalaman Islamic boarding school Bugis-Makasar." In Budaya Damai Komunitas Islamic boarding school, ed. Badrus Sholeh. Jakarta: Pustaka LP3ES Indonesia. 
Bizawie, Zainul Milal. 2014. Laskar Ulama dan Santri: Resolusi Juhad Garda Depan Menegakkan Indonesia (1945-1949). Ciputat: Pustaka Compass.

Dhofier, Zamakhsyari. 2011. Tradisi Islamic boarding school: Studi Pandangan Hidup Kyai dan Visinya Mengenai Masa Depan Indonesia. Jakarta: LP3ES.

Eliraz, Giora. 2007. "Islam and Polity in Indonesia: An Intriguing Case Study." Hudson Institute: Center on Islam, Democracy, and the Future of the Muslim World 1(1): 1-21.

Fahham, Achmad Muchaddam. 2015. Pendidikan Islamic boarding school: Pembentukan Karakter, dan Perlindungan Anak. Jakarta: P3DI Sekretariat Jenderal DPR RI.

Hakim, Lukman. 2016. "Islamic boarding school, Radikalisme dan Ajaran Jihad: Memahami Penafsiran Konsep Jihad di Lingkungan Lembaga Pendidikan Keagamaan Islam Pondok Islamic boarding school." Tekno Efisiensi: Jurnal Ilmiah KORPRI Kopertis Wilayah IV(1): 12335.

Irham, Irham. 2016. "Pesantren Manhaj Salafi: Pendidikan Islam Model Baru di Indonesia." Ulul Albab: Jurnal Studi Islam 17(1): 1-18.

DOI: http://dx.doi.org/10.18860/ua.v17i1.3252.

Kadi, Kadi. 2008. "Pendidikan Islam dan Otonomi Daerah Studi Kasus di Tarbiyatul Mu'allimat Pesantren Walisongo Ngabar Ponorogo." Dialogia 6(2): 313-28.

DOI: https://doi.org/10.21154/dialogia.v6i2.1271.

Laisa, Emna. 2014. "Islam dan Radikalisme." Islamuna: Jurnal Studi Islam $1(2): 1-18$.

DOI: https://doi.org/10.19105/islamuna.v1i1.554.

Ma'arif, Syamsul, Leonard C. Sebastian, and Sholihan Sholihan. 2020. "A Soft Approach to Counter Radicalism: The Role of Traditional Islamic Education." Walisongo: Jurnal Penelitian Sosial Keagamaan 28(1): $1-28$.

DOI: http://dx.doi.org/10.21580/ws.28.1.6294. 
Ma'arif, Syamsul. 2019. "Reinventing Pesantren's Moderation Culture to Build a Democratic Society in the Post-Reform Republic of Indonesia." Pertanika Journal of Social Sciences $\mathcal{E}$ Humanities 27(2): 1739-51.

Marzuki, Marzuki, Miftahuddin Miftahuddin, and Mukhamad Murdiono. 2020. "Multicultural Education in Salaf Pesantren and Prevention of Religious Radicalism in Indonesia.” Cakrawala Pendidikan: Jurnal Ilmiah Pendidikan 39(1): 12-25.

DOI: https://doi.org/10.21831/cp.v39i1.22900.

Mas'ud, Abdurrahman. 2010. "Memahami Agama Damai Dunia Islamic boarding school." In Peranan Islamic boarding school dalam Mengembangkan Budaya Damai, ed. Nuhrison. Jakarta: Badan Litbang dan Diklat Kementerian Agama.

Masduqi, Irwan. 2012. Berislam Secara Toleran: Teologi Kerukunan Umat Beragama. Bandung: Mizan.

Mun'im, Abdul. 2016. "Pergumulan Islamic boarding school dengan Masalah Kebudayaan.” In Budaya Damai Komunitas Islamic boarding school, ed. Badrus Sholeh. Jakarta: Pustaka LP3ES Indonesia.

Muzakki, Akh. 2014. "The Roots, Strategies, and Popular Perception of Islamic Radicalism in Indonesia." Journal of Indonesian Islam 8(1): 122.

DOI: http://dx.doi.org/10.15642/JIIS.2014.8.1.1-22.

Nuryanti, Nuryanti. 2014. "Penanaman Wawasan Kebangsaan di Pondok Islamic boarding school Melalui Pembelajaran Sejarah.” Majalah Ilmiyah Pawiyatan 1: 124-34.

Saifullah, Saifullah. 2014. "Dakwah Multikultural Islamic boarding school Ngalah dalam Meredam Radikalisme Agama.” Islamica: Jurnal Studi Islam 8(2): 422-46.

DOI: https://doi.org/10.15642/islamica.2014.8.2.421-446.

Setiawan, Eko. 2013. "Modernisasi Pola Sistem Pendidikan Pesantren: Studi Kasus Pondok Pesantren Modern Darul Fikri Mulyoagung Dau Malang." Ulul Albab: Jurnal Studi Islam 14(2): 176-93.

DOI: https://doi.org/10.18860/ua.v14i2.2656. 
Sholeh, Badrus. 2007. "Dinamika Baru Islamic boarding school." In Budaya Damai Komunitas Islamic boarding school, ed. Badrus Sholeh. Jakarta: Pustaka LP3ES Indonesia, xxvii-xli.

Susanty, Ary. 2014. Pendidikan Islam Integratif: Studi Analisis Kurikulum di Tarbiyatul Mu'allimat Al-Islamiyah Pondok Pesantren Wali Songo Ngabar Ponorogo. Undergraduate Thesis. UIN Sunan Ampel Surabaya. http://digilib.uinsby.ac.id/1651/

Suyudi, Muhammad, and Azam Syukur Rahmatullah. 2017. "Guru Muthmainnah dalam Perspektif Kyai Pesantren (Studi Terhadap Tiga Kyai Pimpinan Pondok Pesantren Wali Songo Ngabar Ponorogo Jawa Timur)." Inferensi: Jurnal Penelitian Sosial Keagamaan 11(1): 229-46.

DOI: https://doi.org/10.18326/infs13.v11i1.229-246.

Tan, Charlene. 2011. Islamic Education and Indoctrination: The Case in Indonesia. New York: Routledge Taylor \& Francis Group.

Wahid, Abdurrahman. 2009. Ilusi Negara Islam: Ekspansi Gerakan Islam Transnasional di Indonesia. Jakarta: The Wahid Institut.

Zainiyati, Husniyatus Salamah. 2016. "Curriculum, Islamic Understanding and Radical Islamic Movements in Indonesia." Journal of Indonesian Islam 10(2): 285-308.

DOI: http://dx.doi.org/10.15642/JIIS.2016.10.2.285-308.

Ziemek, Mamfred. 1997. Islamic Boarding School Dalam Perubahan Sosial. Jakarta: P3M.

Interview with Nurcholis, Ponorogo, December 11, 2019.

Interview with Kurniadi, Ponorogo, December 11, 2019.

Interview with Toha, Ponorogo, December 20, 2019.

Interview with KH. Heru, Ponorogo, December 20, 2019.

Interview with Ihsan, Ponorogo, January 5, 2020.

Interview with Nahrowi, Ponorogo, January 6, 2020.

Interview with Marjuni, Ponorogo, January 8, 2020. 